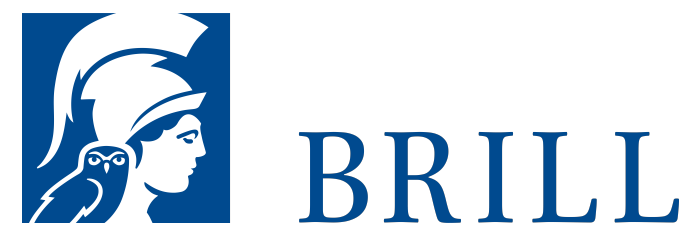

\title{
Language and Ritual in Sabellic Italy
}

The Ritual Complex of the Third and the Fourth Tabulae Iguvinae

Author: Michael Weiss

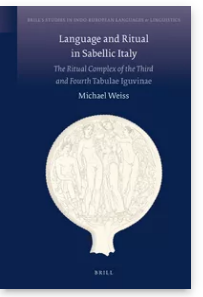

The Iguvine Tables (Tabulae Iguvinae) are among the most invaluable documents of Italic linguistics and religion. Seven bronze tablets discovered in 1444 in the Umbrian town of Gubbio (ancient Iguvium), they record the rites and sacral laws of a priestly brotherhood, the Fratres Atiedii, with a degree of detail unparalleled elsewhere in ancient Italy. Taking an interdisciplinary approach that combines philological and linguistic, as well as ritual analysis, Michael Weiss not only addresses the many interpretive cruces that have puzzled scholars for a century and a half, but also constructs a coherent theory of the entire ritual performance described on Tables III and IV. In addition, Weiss sheds light on many questions of Roman ritual practice and places the Iguvine Tables in their broader Italic and Indo-European contexts.

Readership

This work is of interest to Indo-Europeanists, classical philologists, and students of ancient religion.

Pages: xvi, $5^{16}$

pp.

Language:

English

Subjects: Indo-

European

Languages, Languages and

Linguistics,

Religion,

Classical Studies

Publisher: Brill

Series:

Brill's Studies in Indo-European

Languages \&

Linguistics,

Volume: 1

E-Book (PDF)

Released online:

15 Oct 2009

ISBN: 978-90-

47-44025-3

Hardback

Publication date: 26 Oct 2009

ISBN: 978-9004-17789-5

List price

USD \$264.00 
Michael Weiss, Ph.D. (1993) in Linguistics, Cornell University, is currently a Professor of Linguistics at Cornell University. He has taught in the Classics departments at Yale and the University of North Carolina at Chapel Hill. He has published articles on various aspects of Indo-European, Greek, and Latin linguistics. He is the author of An Outline of the Historical and Comparative Grammar of Latin (Beech Stave, 2009).

For more information see brill.com

$$
\begin{aligned}
& \text { Order information: Order online at brill.com } \\
& \text { +44 } 33 \circ 333 \text { 0049 | customerservices@brill.com } \\
& \text { Submission information: brill.com/authors }
\end{aligned}
$$

Titles published by Brill | Fink, Brill | mentis or Brill | Schöningh: +49(o)71 5413279216 | brill@brocom.de 